\title{
Resilience Models for Children and Teenagers in Learning During the Pandemic
}

\author{
Lidia Sandra ${ }^{1 *}$, Juwaria Muqtadir ${ }^{1}$ \\ ${ }^{1}$ Cendekia Harapan School, Badung, Indonesia \\ *Corresponding author. Email: lidia.sandra@ukrida.ac.id
}

\begin{abstract}
One of the government policy from more than 120 countries is a school closures as the imposition of restrictions on social distancing due to the Corona Virus Disease (COVID-19) pandemic. This has affected 1.6 million students worldwide. In Indonesia, schools have been closed since March 2020, so that approximately 60 million students are given the alternative learning through online processes and remotely throughout the region. It is almost six months for children and teenagers to experience learning during the pandemic. Lack of direct interaction and limited physical activity, are prone to causing problems in mental health and endurance for children and teenagers. This study aims to construct a mental resilience model for children and teenagers in learning during the pandemic situation. The method used is through a Systematic Literature Review (SLR). This method is used to identify, study, evaluate, and interpret research which are relevant to the research topics through by constructing the relevant research questions. Based on the results of the study, it is known that several factors affect mental endurance for children and teenagers in learning during the pandemic, including the ability to adapt to the change, and sustainability of mental health care services. Teenagers reported worse mental health, yet people from various religions and ethnic groups did not differ significantly in reported mental health.
\end{abstract}

Keywords: Child, Mental Resilience, Pandemic

\section{BACKGROUND}

One of the government policy from more than 120 countries is a school closures as the imposition of restrictions on social distancing due to the Corona Virus Disease (COVID-19) pandemic. This has affected 1.6 million students worldwide. In Indonesia, schools have been closed since March 2020, so that approximately 60 million students are given the alternative learning through online processes and remotely throughout the region. It is almost six months for children and teenagers to experience learning during the pandemic. Lack of direct interaction and limited physical activity, are prone to causing problems in mental health and endurance for children and teenagers [1].

The similarity in the situation of the education process in Indonesia with other countries needs to be immediately observed. There are many imbalances in the educational process between regions in Indonesia even in normal circumstances. However, with the arrival of the COVID-19 pandemic, the education process in Indonesia needs to be able to help the condition of schools in general and the mental health of children and teenagers, which is very worrying even though in normal circumstances. Although the use of technology is not considered a problem in the current era of the industrial revolution 4.0 , there are many variety of problems that inhibit the effectiveness of online learning.

The limited space for movement and the lack of interaction with peers during the pandemic have might increase the impact on the mental health of children and teenagers. Hence, it is very important to find the resilience model for children and teenagers to this online learning process. Mental resilience model can enable better planning and interventions for individuals and communities to address the effects of acute pandemics that are expected to impact mental health. There is an urgent need to model the mental resilience in particular in this population [2].

Situations that are so complex and psychologically stressful require attention and prompt treatment so that they do not become a more serious problem for children and teenagers. The vulnerable groups mentioned above are a general portrait of the current condition of society. This paper will briefly review the metal health of the 
community, especially regarding mental resilience in children and teenagers in learning during the COVID-19 pandemic. By using a systematic literature review approach, this paper uses a social psychology perspective in constructing models of resilience in children and teenagers in learning during the COVID-19 pandemic.

\section{STUDY LITERATURE}

Proposed definitions included a stable trajectory of healthy functioning after a highly adverse event; a conscious effort to move forward in an insightful and integrated positive manner as a result of lessons learned from an adverse experience; the capacity of a dynamic system to adapt successfully to disturbances that threaten the viability, function, and development of that system; and a process to harness resources in order to sustain well-being [3].

The 2019 Novel Coronavirus (COVID-19) pandemic is an international public health emergency unprecedented in modern history 1 . Besides the biological context, and due to the wide and long- lasting changes in daily life it may cause, coping with it represents a challenge to psychological resilience. Previous studies have shown that epidemics and contamination outbreaks of diseases have been followed by drastic individual and social psychosocial impacts, which eventually become more pervasive than the epidemic itself 2,3. Currently, due to this pandemic, high levels of anxiety, stress and depression have already been observed in the general population [4].

The World Health Organization (WHO) reports that by far, the largest public mental health impact has been in the form of stress and anxiety, and predicts a rise in depression, suicide and substance use in the coming days [5].

According to a recently developed emotional epidemic curve without adequate mitigation measures, countries will experience two peaks of negative mental health consequences. The first peak is dominated by anxiety and corresponds to the peak in COVID-19 cases. A second peak of negative mental health outcomes comprising of Post-Traumatic Stress Disorder (PTSD), depression, suicide, complicated grief bereavement, and relapse of those with existing disorders, corresponds to the post-pandemic period. Given the substantial anticipated burden of mental disorders in the context of the COVID-19 pandemic, it is important that the mental health response is given high priority [5].

Emotional resilience, defined as the ability to generate positive emotions and recover quickly from negative emotional experiences, is an important component of psychological resilience. It has 2 basic elements: the ability to generate positive emotions when facing negative emotional stimuli and the ability to recover from negative emotional experiences. Emotional resilience is more likely to lead to emotionally directed coping, which is related to the individual's emotion- al efforts in stressful situations. This adaptive mechanism re- stores and maintains normal emotional levels in the face of major events. Through interaction between the individual and the environment, adaptation can occur. Emotional resilience has a substantial impact on the individual's mental health and social adaptation. Differences in emotional resilience may lead to individual differences in emotional responses, which in turn affect cognitive processing of emotional information.

According to Reivich and Shatte, which is described in their book "The Resilience Factor", it is explained that resilience is the ability to adapt and cope with severe events and situations or problems that occur in life. There are seven aspects that build resilience in an individual. These aspects are emotion regulation, impulse control, optimism, causal analysis, empathy, self-efficacy, and reaching out. Emotion regulation is the ability to remain calm under stressful conditions. Next is impulse control, where the individual has the ability to control the desires, preferences, or pressures that arise from within the individual. Optimism is an attitude when an individual sees a bright future, while Causal analysis refers to the individual's ability to identify what are the causes or factors of the problem being faced accurately and correctly. Empathy is closely related to an individual's ability to read signs of other people's emotional and psychological conditions. Self-efficacy is the result of successful problem alleviation and finally, reaching out is an individual's ability to reap the positives of life where he has experienced adversity in his life [6].

There are three general classes of resilience models: compensatory, protective, and challenge, that explain how resilience factors operate to alter the trajectory from risk exposure to negative outcome [7].

A compensatory model best explains a situation where a resilience factor counteracts or operates in an opposite direction to a risk factor. The resilience factor has a direct effect on the outcome, one that is independent of the effect of the risk factor. In CIET's ACYRN-East study, for example, alcohol abstinence or moderation is compensatory in the sense that it is directly and independently associated with lower risk for youth suicide [7].

In the protective model, assets or resources moderate or reduce the effects of a risk on a negative outcome. Protective factors may operate in several ways to influence outcomes. They may help to neutralize the effects of risks; they may weaken, but not completely remove them; or they may enhance the positive effect of another promotive factor in producing an outcome. In the ACYRN-East study, being drug-free, though not directly associated with lower suicide risk, is associated with 
lower alcohol use and thus is protective in the sense that it enhances the latter's anti-suicide potential [7].

A third model of resilience is the challenge model. In this model, the association between a risk factor and an outcome is "curvilinear": exposures to both low and high levels of a risk factor are associated with negative outcomes, but moderate levels of the risk are related to less negative (or positive) outcomes. Adolescents exposed to moderate levels of risk, for example, may be confronted with enough of the risk factor to learn how to overcome it but are not exposed to so much of it that overcoming it is impossible. Many challenge models require longitudinal data. Researchers use them, for example, to track how repeated exposure to challenges prepares adolescents for dealing with adversities in the future [7].

An interesting application of the challenge model of resilience is provided by Richardson (2002) for whom "resilient reintegration" is the most positive outcome of a process involving an individual's reactions to some stress or adversity. Resilient reintegration occurs when one experiences some insight or growth as a result of disruption. It results in the identification or strengthening of resilient qualities. According to the underlying theory, individuals are genetically predisposed with more potential than they are conscious of. The "disruptive resiliency process" is a means to access this potential [7].

\section{METHODOLOGY}

The method used is through a Systematic Literature Review (SLR). This method is used to identify, study, evaluate, and interpret research which are relevant to the research topics through by constructing the relevant research questions.

\subsection{Scoping Review}

PCC (Population, Concept, and Context) framework is to identify the main concepts in primary review questions. The PCC mnemonic is recommended as a guide to construct a clear and meaningful title for a scoping review. In this study, the population of study is children and teenagers, the concept is resilience model, and the context is in learning and during pandemic.

\subsection{Research Method}

\subsubsection{Research Question}

Research Question was made based on the needs of the research. Here is the research question of this study.

RQ1. What is the resilience process in children and teenagers in learning during the COVID-19 pandemic?
RQ2. What is the connection between the factors of children's and teenager's resilience?

\subsubsection{Search Process}

Search Process is used to get a relevant resources to answer the Research Question (RQ) and other references. The finding process is using the search engines in electronic searches journals namely: ProQuest, Emerald, and EBSCO to search the primary data and search engine to search the secondary data.

\subsubsection{Inclusion and Exclusion Criteria}

This steps is to decide whether the data is relevant and fit with the SLR research. The criteria for this journal study are human research, free full text, in English, and published in 2015-2020. The keywords used in the search are; "((mental resilience OR mental health) AND (teen OR child OR adolescent) AND (learning) AND (pandemic OR COVID-19))". From the search found articles available in free full text, 245 journals in total. This article can describe mental resilience in children and teenagers. From 245 journals, then the researchers selected them using the research questions, and its turn out into 24 journals. From 24 journals, 8 journals chosen based on the criteria for this journal study.

\subsubsection{Data Collection}

Data collection or data collection is the stage where data for research is collected. The data collected in this study are primary and secondary data. Primary data is information collected through surveys, interviews, observations, and adjusted as required. Secondary data is used to complement the primary data, if there are only abstracts in the primary data, secondary data is needed to complete the primary data. Secondary data is obtained using search engine. Data collected and to be safed in Mendeley Software.

\section{RESULT AND DISCUSSION}

Based on the previous study, the impact of the COVID-19 pandemic can cause the children and teenagers feel stressed, anxious, and concerned. Besides, fear of getting sick, the loss of a loved one, as well as feelings of annoyance, tiredness, sadness and loneliness due to quarantine (Table 1.).

Online learning that limits physical interaction causes no social interaction, so verbal and non-verbal communication is not used correctly. In the learning conditions, students complain about situations that burden them in learning. Lack of social support makes students experience emotional disturbances. In the end, learning was felt to be less effective, primarily when two weeks after education was carried out. To reduce emotional disturbances, some students try to build 
communication with lecturers to tolerate tasks that they think are so heavy [8].

A study also shows that the stability of family income is also a significant factor in anxiety experienced by students during the COVID-19 crisis, which can be explained by increased psychological and economic stress (Liu, 2013). All research subjects chose to return to their hometowns to reduce the burden on family expenses. According to some studies, living together with parents at the time of the COVID-19 outbreak will reduce anxiety and psychological problems. By living with parents, according to the research subjects, they can also help parents, both in terms of family finances and help others [8].

Based on the study by Chen, et al., [9], risk factors for adolescents' mental health condition during the COVID19 are less warm and supportive, more protective, more emotional rejection. And the decline of parents' emotional warmth. This can cause mental health concerns, such as stress related to the pandemic, abrupt disruptions to daily life, anxiety about illness, social isolation, and interrupted connectedness to school [10].
In other study by Witt, et al. [11] mentioned that the psychological impact of quarantine are posttraumatic stress, confusion and anger, boredom and frustration lead to family stress and conflicts. To reduce its accompanying negative psychological effects, parents or school community can provide childcare and to support distance-learning efforts and try to give more information and knowledge on how to manage the impact of disease.

The study from Zhang, et al. [12] explored the emotional resilience of middle school students learning at home in February and March 2020 during the COVID19 pandemic, and the impact of this resilience on students' learning management skills. The result showed that emotional resilience was significantly lower in eighth grade students than in seventh grade students. Besides, negative emotional recovery increased during the study period and emotional resilience was positively correlated with learning management skills. Lastly, positive emotions had a strong predictive effect on learning management skills.

Table 1. Literature Review Journal List and Content

\begin{tabular}{|c|c|c|c|c|}
\hline No. & $\begin{array}{l}\text { Name of the } \\
\text { Author(s) }\end{array}$ & Title & Method & Result \\
\hline 1 & $\begin{array}{l}\text { Shitao Chen, } \\
\text { Zeyuan Cheng, } \\
\text { and Jing Wu } \\
\text { (2020) }\end{array}$ & $\begin{array}{l}\text { Risk Factors for } \\
\text { Adolescents' Mental } \\
\text { Health During the } \\
\text { COVID-19 Pandemic: } \\
\text { A Comparison } \\
\text { Between Wuhan and } \\
\text { Other Urban Areas in } \\
\text { China }\end{array}$ & \begin{tabular}{|l|} 
Quantitative by \\
Structural \\
Equation \\
Modeling \\
(SEM)
\end{tabular} & $\begin{array}{l}\text { Risk factors for adolescents' mental health condition } \\
\text { during the COVID-19: } \\
\text { - Less warm and supportive, more protective } \\
\text { - More emotional rejection } \\
\text { - The decline of parents' emotional warmth }\end{array}$ \\
\hline 2 & $\begin{array}{l}\text { Rebecca T. Leeb, } \\
\text { Rebecca H. Bitsko, } \\
\text { Lakshmi } \\
\text { Radhakrishnan, } \\
\text { Pedro Martinez, } \\
\text { Rashid Njai, and } \\
\text { Kristin M. Holland } \\
(2020)\end{array}$ & $\begin{array}{l}\text { Mental Health-Related } \\
\text { Emergency } \\
\text { Department Visits } \\
\text { Among Children Aged } \\
<18 \text { Years During the } \\
\text { COVID-19 Pandemic } \\
\text { - United States, } \\
\text { January 1-October 17, } \\
2020\end{array}$ & $\begin{array}{l}\text { Quantitative by } \\
\text { Survey }\end{array}$ & $\begin{array}{l}\text { Mental health concerns: } \\
\text { - Stress related to the pandemic } \\
\text { - Abrupt disruptions to daily life } \\
\text { - Anxiety about illness } \\
\text { - Social isolation } \\
\text { - Interrupted connectedness to school. } \\
\text { The implications for public health practice: } \\
\text { - Monitoring indicators of children's mental health } \\
\text { - Promoting coping and resilience } \\
\text { - Expanding access to services to support children's } \\
\text { mental health }\end{array}$ \\
\hline 3 & $\begin{array}{l}\text { Andreas Witt, Anna } \\
\text { Ordóñez, Andrés } \\
\text { Martin, Benedetto } \\
\text { Vitiello, and Jörg } \\
\text { M. Fegert (2020) }\end{array}$ & $\begin{array}{l}\text { Child and Adolescent } \\
\text { Mental Health Service } \\
\text { Provision and } \\
\text { Research During the } \\
\text { COVID-19 Pandemic: } \\
\text { Challenges, } \\
\text { Opportunities, and A } \\
\text { Call For Submissions }\end{array}$ & $\begin{array}{l}\text { Qualitative by } \\
\text { Study Literature }\end{array}$ & $\begin{array}{l}\text { The psychological impact of quarantine: } \\
\text { - Posttraumatic stress } \\
\text { - Confusion and anger } \\
\text { - Boredom and frustration lead to family stress and } \\
\text { conflicts } \\
\text { How to reduce its accompanying negative } \\
\text { psychological effects: } \\
\text { - Provide childcare and to support distance-learning } \\
\text { efforts Manage the impact of disease }\end{array}$ \\
\hline 4 & $\begin{array}{l}\text { Deshinta Vibriyanti } \\
(2020)\end{array}$ & $\begin{array}{l}\text { Society Mental Health: } \\
\text { Managing Anxiety } \\
\text { During Pandemic } \\
\text { COVID-19 }\end{array}$ & \begin{tabular}{|l|} 
Qualitative by \\
Study Literature
\end{tabular} & $\begin{array}{l}\text { The process of anxiety in dealing with the COVID-19 } \\
\text { pandemic: } \\
\text { - Manage anxiety } \\
\text { - Adapting to pandemic conditions }\end{array}$ \\
\hline 5 & $\begin{array}{l}\text { Andi Wahyu } \\
\text { Irawan, Dwisona, }\end{array}$ & $\begin{array}{l}\text { Psychological Impacts } \\
\text { of Students on Online }\end{array}$ & \begin{tabular}{|l|} 
Quantitative by \\
Purposive \\
Sampling
\end{tabular} & $\begin{array}{l}\text { Psychological conditions during the COVID-19: } \\
\text { - Saturated with online learning } \\
\text { - Considerable anxiety about parents' earnings }\end{array}$ \\
\hline
\end{tabular}




\begin{tabular}{|c|c|c|c|c|}
\hline No. & $\begin{array}{l}\text { Name of the } \\
\text { Author(s) }\end{array}$ & Title & Method & Result \\
\hline & $\begin{array}{l}\text { and Mardi Lestari } \\
(2020)\end{array}$ & $\begin{array}{l}\text { Learning During the } \\
\text { Pandemic COVID-19 }\end{array}$ & & Emotional disturbances \\
\hline 6 & $\begin{array}{l}\text { Qing Zhang, } \\
\text { Longjun Zhou, and } \\
\text { Jianping Xia (2020) }\end{array}$ & $\begin{array}{l}\text { Impact of COVID-19 } \\
\text { on Emotional } \\
\text { Resilience and } \\
\text { Learning Management } \\
\text { of Middle School } \\
\text { Students }\end{array}$ & $\begin{array}{l}\text { Quantitative by } \\
\text { Survey }\end{array}$ & $\begin{array}{l}\text { The impact of the COVID-19 pandemic: } \\
\text { - Emotional resilience was significantly lower in eighth } \\
\text { grade students than in seventh grade students } \\
\text { - Negative emotional recovery increased during the } \\
\text { study period. } \\
\text { - Emotional resilience was positively correlated with } \\
\text { learning management skills } \\
\text { Positive emotions had a strong predictive } \\
\text { effect on learning management skills. }\end{array}$ \\
\hline 7 & $\begin{array}{l}\text { ContentEngine } \\
\text { LLC (2020) }\end{array}$ & $\begin{array}{l}\text { The Mental Health of } \\
\text { Adolescents Affected } \\
\text { by the COVID-19 } \\
\text { Pandemic }\end{array}$ & $\begin{array}{l}\text { Quantitative by } \\
\text { Survey }\end{array}$ & $\begin{array}{l}\text { The impact of the COVID-19 pandemic: } \\
\text { - Feel stressed, anxious, and concerned } \\
\text { - Fear of getting sick, the loss of a loved one, } \\
\text { as well as feelings of annoyance, tiredness, sadness } \\
\text { and loneliness due to quarantine. }\end{array}$ \\
\hline
\end{tabular}

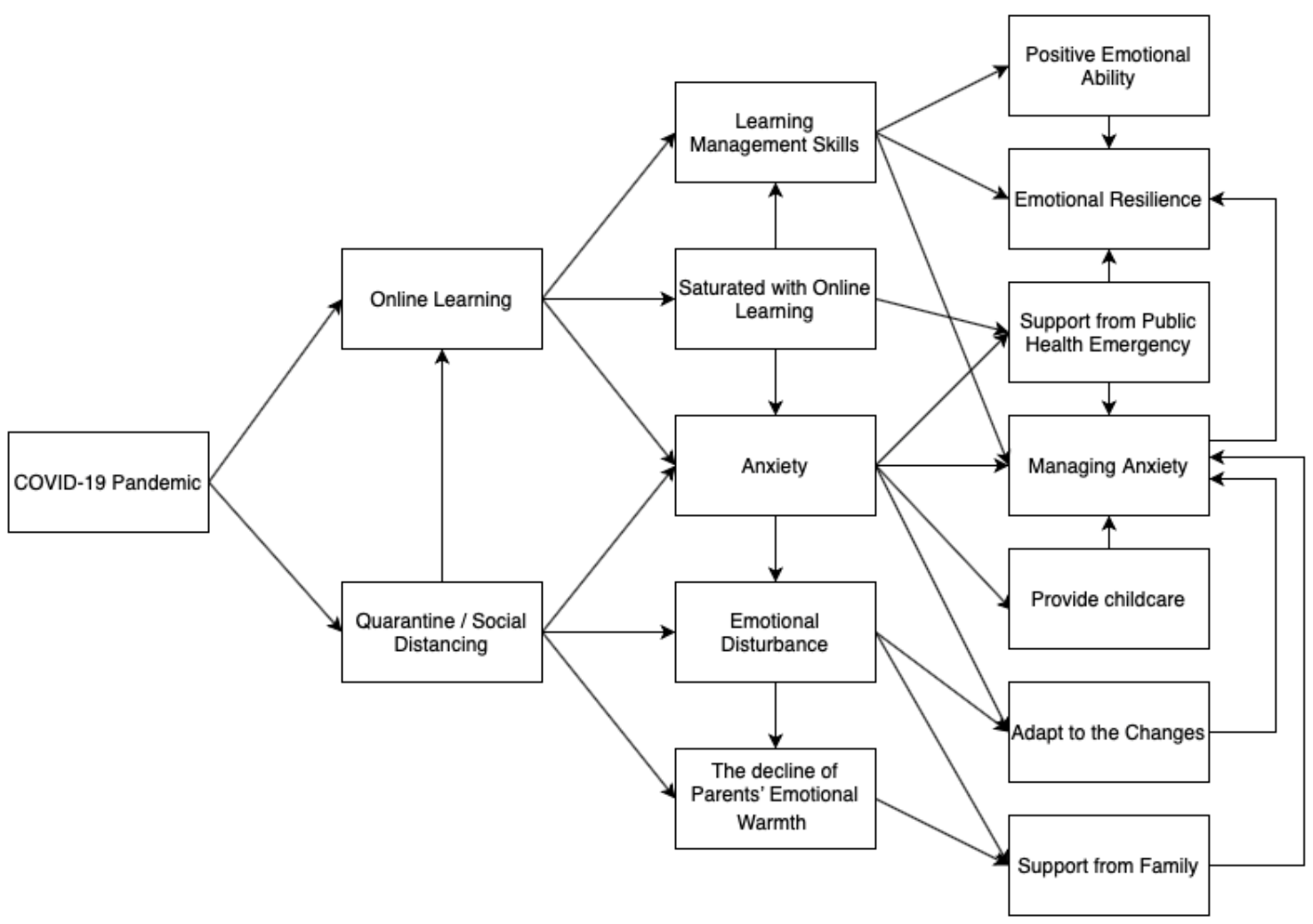

Figure 1 Resilience Model for Children and Teenagers in Learning during COVID-19 Pandemic

Based on the results of the study, it is known that several factors affect mental resilience for children and teenagers in learning during the pandemic, including the ability to manage the anxiety, adapt to the change, the role of family and teachers, and sustainability of mental health care services. Besides, continuous support, assessment, evaluation and mentoring from many stakeholders, such as parents, teachers, society, and government will be very beneficial as factors affected children and teenagers' mental resilience (Figure 1.). The role of a psychologists is important to determine the extent to which individuals benefit from positive emotions and to design interventions that promote happiness and a more fulfilling and satisfactory life. Improving the positive emotional experiences should be started in the early age because the stable emotional, attitudinal, and motivational patterns found in adulthood are established early in life [13].

The resilience models can also be improved from which seven aspects that build resilience in an individual, based on Reivich and Shatte [6] study. These aspects are emotion regulation, impulse control, optimism, causal analysis, empathy, self-efficacy, and reaching out. 


\section{CONCLUSION}

Several factors affect mental resilience for children and teenagers in learning during the pandemic, including the ability to manage the anxiety, adapt to the change, the role of family and teachers, and sustainability of mental health care services. Besides, continuous support, assessment, evaluation and mentoring from many stakeholders, such as parents, teachers, society, and government will be very beneficial as factors affected children and teenagers' mental resilience. Improving the positive emotional experiences should be started in the early age because the stable emotional, attitudinal, and motivational patterns found in adulthood are established early in life.

\section{RECOMMENDATION}

Children and teenagers mental health is greatly affected when faced with a public health emergency, and they need attention, help, and support from the community, family, and tertiary institutions. It is recommended that the government and schools should collaborate to solve this problem by providing psychological services. Psychologists and counsellors can work to offer online services to overcome the effects of COVID-19. For future researchers, it is recommended to research a solutive effort to overcome the psychological impact of the COVID-19 pandemic.

\section{REFERENCES}

[1] D. R. Rai, G. Mathew, A Review on Theories and Models of Disease Causation for COVID-19, 2020. DOI: https://orcid.org/0000-0003-0560-2150.

[2] Prihastuti, Profil Resiliensi Pendidik Berdasarkan Resilience Quetient Test, in: Jurnal Penelitian dan Evaluasi Pendidikan, vol. 15(2), 2011, pp. 199-214. DOI: https://doi.org/10.21831/pep.v15i2.1102.

[3] S. M. Southwick, G. A. Bonanno, A. S. Masten, C. Panter-Brick, and R. Yehuda, R, Resilience definitions, theory, and challenges: interdisciplinary perspectives, in: European Journal of Psychotraumatology, vol. 5(25338), 2020, pp. 1-14. DOI: http://dx.doi.org/10.3402/ejpt.v5.25338.

[4] F. Ornell, S. C. Halpern, F. H. P. Kessler, J. C. M. Narvaez, The impact of the COVID-19 pandemic on the mental health of healthcare professionals. Cad. Saúde Pública, vol. 36(4), 2020, pp. 1-6. DOI: http://dx.doi.org/10.1590/0102-311X00063520.

[5] F. Jaguga, E. Kwobah, Mental health response to the COVID-19 pandemic in Kenya: a review, in: International Journal of Mental Health Systems, vol. 14(68), 2020, pp. 1-6. DOI: https://doi.org/10.1186/s13033-020-00400-8.
[6] K. Reivich, A. Shatte, The Resilience Factors: 7 keys to finding your inner, strength, and overcoming life's hurdles, Amerika : Broadway Books, 2003.

[7] J. Fleming, R. J. Ledogar, Resilience, an Evolving Concept: A Review of Literature Relevant to Aboriginal Research, in: Pimatisiwin, 6(2), 2008, 7 23.

https://www.ncbi.nlm.nih.gov/pmc/articles/PMC29 56753/pdf/nihms387.pdf.

[8] A. W. Irawan, Dwisona, and M. Lestari, (2020). Psychological Impacts of Students on Online Learning During the Pandemic COVID-19, in: Jurnal Bimbingan dan Konseling (E-Journal), vol. $7(1), \quad 2020, \quad 53-60 . \quad$ DOI: https://doi.org/10.24042/kons.v7i1.6389.

[9] S. Chen, Z. Cheng, and J. Wu, Risk Factors for Adolescents' Mental Health During the COVID-19 Pandemic: A Comparison Between Wuhan and Other Urban Areas in China, in: Globalization and Health, vol. 16(96), 2020, 1-11. DOI: https://doi.org/10.1186/s12992-020-00627-7.

[10] R. T. Leeb, R. H. Bitsko, L. Radhakrishnan, P. Martinez, R. Njai, and K. M. Holland, Mental Health-Related Emergency Department Visits Among Children Aged $<18$ Years During the COVID-19 Pandemic - United States, Morbidity and Mortality Weekly Report, US Department of Health and Human Services, vol. 69(45), 2020, pp.1675-1680.

[11] A. Witt, A. Ordóñez, A. Martin, B. Vitiello, and J. M. Fegert, Child and Adolescent Mental Health Service Provision and Research During the COVID19 Pandemic: Challenges, Opportunities, and A Call For Submissions. Child and Adolescent Psychiatry and Mental Health, vol. 14(19), 2020, pp. 1-4. DOI: https://doi.org/10.1186/s13034-020-00324-8.

[12] Q. Zhang, L. Zhou, J. Xia, Impact of COVID-19 on Emotional Resilience and Learning Management of Middle School Students, in: Clinical Research, 26, 2020, pp. $1-8 . \quad$ DOI: https://doi.org/0.12659/MSM.92499

[13] L. Oros, Studies on Positive Emotions in Children: Current Status and Future Direction, 2014.

[14] D. Vibriyanti, Kesehatan Mental Masyarakat: Mengelola Kecemasan Di Tengah Pandemi COVID-19, in: Jurnal Kependudukan Indonesia, 2020, pp. 69-74. 